《第178回順天堂医学会学術集会》

\title{
覀性腫瘍と外科に関する討論会
}

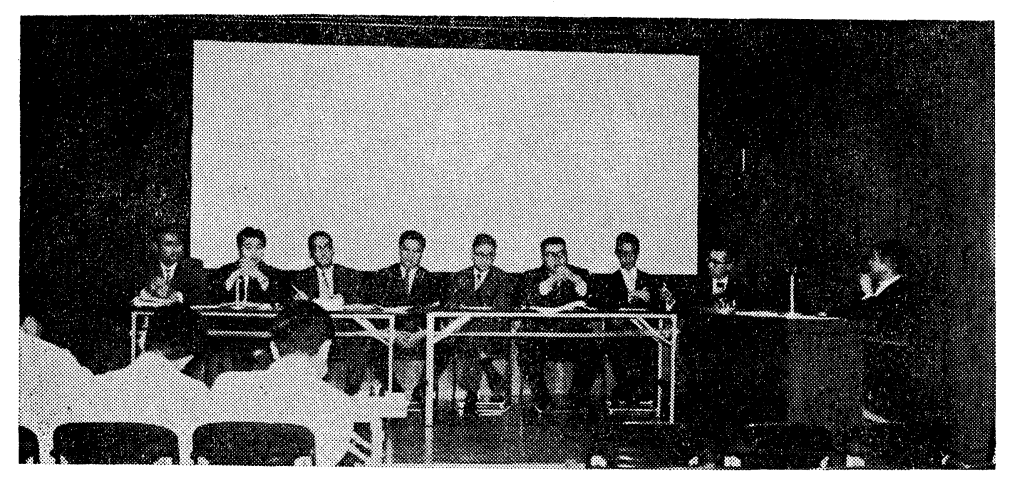

司会 教授 村上 忠重
(一般外科学)
講師 三枝 清純

(整形外科学)

助教授 千ケ崎裕夫

(脳外科学)

助手 板谷年雄
(胸部外科学)

講師安井昭

(一般外科学)

助手 河野 澄男

助教授 野中 博

(泌尿器科学)

講師 長峰 敏治

(産婦人科学)

助手 栗原稔

助教授 長瀬 勝也

(放射線医学)

村上 只今から「悪性腫瘍と外科」と云う主題 で御集りの先生方に 御討論いただきたいと思いま 于.

私の方でこの主題のもとで御討論いただくため にあげさせていただきました項目は次の様なもの です.

(1) 悪性腫瘍の治療の実態（最近 5 〜 年の統計）

(2) 根治手術に対する考方方

(1) 根治手術適応決定に関する問題

(D) リンパ節廓清について

（）血管移植の必要性

(3) 姑息手術に対する考光方

(4) 根治手術および姑息手術の予後の違い（例兄 ば 3〜 5 年生存率)

(5) 放射線併用の価值

(6) 制癌剂の効用

(7) 術後の機能欠損に対する対策（アフタケアの 問題)

(8) 将来に対する Vision

まず最初の “悪性腫瘍の治療の実態”につきま
乙ては, 最近の 10 年間或いは 5 年間の統計を皆様 大体論文の中に織りまぜていただきましたので， 特に申乙上げる必要はないと思います。

2 番目の，根治手術というものに対する考方方 について打話しいただきたいんですが，これは， 大体先ほどお話しいただいた順番に，根治手術適 応に関する問題とリスク，根治手術ができれば一 番いいんですが，これに対してリスクという問題 があります。体根治手術がそれぞれの疾患に拉 いて何\%ぐらい行なわれているかといらことが問 題で，しかもとれに対してリスクということがど のよ5に考觉られているか，たとえば老人である とか，あるいは非常に若い赤ちゃんであるとかい ったような問題でございます。これについて何か 扮考觉がありましたら，順番に三枝先生のほうか ら和話しいただければと思います。なるべく簡単 に，たとえば根治手術はらちの手術の中の $50 \%$ を 占めていて，そのうちでこういう問題をリスクと して一番注意していると、こういうふらに和話し いだたけるとありがたいと思います。 
三枝 先ほども申し上げをしたように整形外科 の腫湯は，悪性度の高い腫湯であるため，ほかの 科が非常にいい成績なのに比べて，非常に成績が 劣っているように思われます。すず治療というこ とでございますが，早期発見ということがまず問 題になると思います。

村上それはわかります。現状……

三枝 現状では，整形を患者が訪れました時点 で，胸部にメタスターゼがさているとか，そうい った症例が現状では非常に多うございむす。それ で，手術の適応とかいらことが扔のずと変わって まいりますが，一応根治手術というふらにして考 えた場合に四肢ということに限って申し上げます と，まず切断，あるいは関節離断ということを行 ないます．この場合に，肺その他の組織に，検査 でメタスターゼがないという場合に行ないます。

もう1つは，非常に疼痛が出てくる場合があり まして，この場合に肺に多少小さな陰影があって も切断を行なうというような場合があります。こ れは根治手術にならぬかもしれませんが，そらい らことをやって和ります。

それから，その手術を行なったあとで制ガン剂 の大量間歇的投与を行います。

村上 制癌剤の問題はまたあとで述べていただ くことにしまして，まず手術だけでこれは根治で きる，あるいは根治をさせようとする場合，足を 全部切ってでも根治させようとするのか，なるべ く残すのか，足を全部切るような手術が四肢の腫 瘍に対して何\%ぐらい行なわれているか，あるい はパーセントがご無理でしたら 3 分の 1 とか 5 分 の 1 とかという称えでけっこうです。

三枝 パーセンテージでいきますと非常に少な く, 半分ぐらいになるかと思います.

村上わかりました。

千ケ崎先生のところも同様これは困らせる質問 になることは先ほどの和話でわかって拈ります が，たと壳ばメニンジオーマ(髄膜腫)ならメニ ンジオーマだけに限ったらどのくらいになるかと いうことでございます。

千ケ崎 先ほど述べましたように，脳腫癔の場
合には身体他部の腫瘍と比べて，かなり悪性腫瘍 の考方方が違いますので，根治手術という言葉が どういら内容を指しているかむつかしいのですけ れぞも病理学的悪性腫瘍の代表であるグリオーム に関しては少くとも根治手術は不可能でありま す.それから病理的には良性でも，発生部位が問 題で, 臨床的に悪性とい5腫瘍に関しては, 今日 の手術手法をもってはほとんど $90 \%$ 近く全摘が可 能になってきたんじゃないかと私は思って和りま 于.

村上ありがとうございました。

板谷 肺ガン全体から申乙上げますと，先ほど 怙示ししたよ5に，27.1\%の切除率しかございま せん，そのうち一応私たちが根治手術といいます のは原発の病巣が肺内に限局して战りまして，手 術の際に肺門及び縱隔のリンパ腺がすべて 廓清で きた症例を根治手術として扣りますけれども，43 例中ちょうど半分, 21 例が根治切除できておりま 于.

村上 切除できたもののうちの半分ということ でございますね.

板谷 そういうことです。

安井 根治手術というのは，先ほど申しました ように胃ガン研究会取り报い規約によって私ども やっているわけですが，早期ガンでは $100 \%$ 近く に根治手術ができます。とれから，進行ガンでは 大体 $60 \%$ 程度だと思います。

村上 進行ガンの $60 \%$ ですか.

安井 え光，そうです。

河野 小児外科のほうでは腹部腫瘍といらこと になりますとすくく栄養状態が悪くなり，全身状 態が悪くなります．したがって，先ほども説明い たしましたが48時間以内に診断をつけて治療に持 っていくことが大切です.この早期診断を前提と しまして, 根治手術と云うものが問題となって来 ます．根治手術と考学られる手術の率としては小 児期の外科的悪性腫瘍として代表的なウィルムス 腫湟の場合で大体 $87 \%$, 神経ガ芽細胞腫のほ 5 は 48\%です.この数字は全国統計で，われわれの経 験ではウィルムスは全例摘出できておりますし， 
神経ガ芽細胞腫のほうは, 約半数例 ほどで全摘出 が括こなわれて和ります。

長瀬 子宮頝ガンだけに限って申しますと大体 60\%ぐらいに現在やって和ります。

村上ありがとうございました。

野中 数を出すのはむづかしいんですけれども

村上 大体の感じでケっこうです.

野中 膀胱全摘といっても，先活ど和話しした と抢りの成績ですから，根治し得るという可能性 がむずかしいんですけれども，もちろん浸潤のな いものでは 1 回の治療であと完全治癒の可能性が あります。

村上 結果は, もちろん根治手術をやったから といったって，その中のまた何\%かが死んだり生 さたりする・だから，こいつは根治手術ができる とい5見込みが膀胱腫瘍……

野中ですから，先ほど stage C までのもので したら全摘をやってうまく尿路管理ができれば根 治できると思います。.

村上じゃCまでが何\%ありますか。

野中 それは，いまの症例では詳しく調べてあ りませんからわかりません。

村上 半分以下, 半分以上.

野中 Cまでなら，かなりの数です.

村上 膀胱腫疸全部に根治手術ができますか？

野中 いや，リンパ節転移のあるものは膀胱全 剔を行っても根治手術になりませんので D沈 めで，Dは初晾時で和そらく10\%ぐらいの範囲じ やないかと思います。

村上 大体 $90 \%$ に.......

野中 やればできすすけれども，先ほど申しま したように膀胱全剔には必然的に尿路変更を伴い ますのでなるべく臓器保存の方法で進めています から，できれば部分的別除の方針です.

村上ついでにも51つ, リスクの問題で, 年 令はいくつまでぐらいなら無条件でおやりになり ますか.

野中 無条件となりますと70歳.

村上 長峰先生いかがですか.
長瀬 大体65歳ぐらいまで.

村上 河野さんのところは, 逆に小さい子供.

河野 腫演の性質にもよると思いますが，新生 児すなわち生後28日以内でも充分にやれます.

安井 大体70歳.

板谷私たちは肺機能といらことがありますの で，パーセントで VCが60\%以上であれば，大体 65 歳.

千ケ崎 特別に年令の制限がありませんけれぞ も，一応手術をして，おとその患者さんが有益な 生活を送れる状態ならば何歳でもできます。

村上 年令はあまり関係がない。

千ケ崎はい。

三枝 整形では75歳が最高です.

村上そのほか，各科で特別に，いまの千ケ崎 先生のように，生きていたって廃人になっては意 味がないので，こういう条件をつけて根治手術の 選び方をする，あるいはリスクを選定する。こう いったようなことについて, 各科特有の, ほかの 科と違った面，そういうものをつけ加えていただ く必要がございましたら，その方だけひとつお願 いいたします。

千ケ崎 脳神経科の領域で，この問題は各自の フィロソフィの問題につながりますので，一定の 基準はありません，人によっては非常に敩格な基 準を設ける人がありまして，たと学げ手術後失語 症を起こすような患者さんの場合は人間的には意 味がないと考党る非常にきびしい人もあります し, ある程度ことばの障害がきても, 普通の生活 が何とかできればいいのではないかという甘い基 準の人もあります，倫理観の問題で何ともい党ま せん。

板谷 私たちも一応根治切除の条件として，な るべく全摘は避けて葉切にとどめるようにしてお ります.

安井 早期ガンは別でありますが，進行ガンの 場合は，まず漿膜面にガンが出ている場合でござ いますが，それでもはっきり出ているとか，他の 臟器にメタがあるという場合, それから血行性に 転移のあるような肝臟に肉眼的に見ましてガンが 
あるとか，そういうような場合とか，腹膜に播種 があるというような場合には一応根治手術の対象 から規約上はずされておりまずそうでないもっ と早期のものに対して根治手術をしております.

村上どうもありがとうございました。

それでは次の項目にいきましょう，その根治手 術をなさいますときに, 一定のリンパ節廓清術, いままでいろいろ括話がございましたが，これは 血行転移してしまいますといまの段階では手術で は防ぎようがない。まあリンパ腺転移ならば何と かまだメスで追っかける可能性があるわけです。 このリンパ節に対する廓清のしかたが，根治手術 である程度きまっているか，あるいはそこまでは きまっていなくて，ケース・バイ・ケースでやっ ている.こういうようなことを，きまっている， あるいはきまっていない，というふうに和答劣い ただけるとありがたいと思います。括それ入りま すがも5 1 回三枝先生のほうから，たと兊ば四肢 烺局していただいてけっこうです。

三枝，四肢の場合ば肉腫でございますので，血 行転移が多いので特にリンパ腺廓清ということ は，ときにやりますが，普通きまって和りません，

村上 ケース・バイ・ケースといらことですね.

千ケ崎 脳腫湟の場合は幸いなことに単発性が 玨とんどでして，転移を和こすことはほとんどあ りませんので, リンパ節の問題はあまり関係があ りません。

板谷 私たちは，鎖骨上にリンパ節の転移があ った場合は，絶対に手術いたしません，手術適応 の症例は, 開胸いたしまして, 肉眼的に縦隔ある いは肺門のリンパ節に腫脹がある場合は, 必ずそ

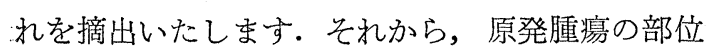
によりまして, 特有の肺内のリンパの流れがござ います。したがって，それに沿ったリンパ節は， 必ず摘出するようにいたして和ります。

村上ちょっと伺います。これは私が恥をかく ことになるかもしれません，先㴽どのは前斜角筋 のプンクチオンによるパイオプシーですか.

板谷、プローベです.

村上これで晾断がついた場合に根治手術は可
能ですか.

板谷 不可能だと思います。

安井 胃ガンの場合は, かなり厳密にリンパ腺 の廓清についてはきまっでります。

河野 小児の腹部腫瘍の場合は, 周囲のリンパ 節を中心として後腹膜リンパ節をかなり広汎にや るようにしています。しかし，その方法について は全国的なとり決めは今の所ありません，昨年来 日本小児外科学会の悪性腫瘍委員会でいろんな方 向づけがされて拈りまして，間もなく一つの規準 がしめされると思います。

村上もら少しで, そ5いら定型的な廓清術が 制定されようとしているわけですね.

河野はい。

長峰 子宮䅡ガンに拉きむしては, 根治手術と いうのはリンパ節廓清を必ずやっています。

野中 膀胱の場合は全摘をすれば, リンパ腺を なるべくとるようにして拉ります。

村上 それはなるべくであって……

野中 腫脹のあるものは勿論，とります。

村上 取り方がきまっているわけ……

野中きまった方法はありません。

村上とうしますと，いま括話があったのをま そめますと，肺ガン，胃ガン，子宮ガンについて は，ほぼ厳格な廓清のしかたがきまっている・な 伃，小児外科の腹部の腫湯については，いま全国 的なきめ方が制定されつつある. そういうふらに 理解してよろしいと思いますが，いかがでござい ましょらか。よろしゅうございますか一それで は,ぞらもありがとうございました。

その次，今度は根治手術を非常に極端に推し進 めますと，たとえばいまのリンパ節が血管につい ているときにはやめるとかというょうな問題，必 ずとこに血管という問題が出てまいます。 あくま で血管まで，血管にくっついていたら，血管を切 っても，血管移植をやってもとるという，そこま での报話はちょっとなかったように思うんです が，あるいはそういらところまでやってみたい。 近い将来卆らいうふらにしたい，あるいはとらい ら経験がある，こらいったことで，血管に手を加 
えることによって根治性を増すということに関し てのご経験なり，近い将来に郝ける希望なり，あ るいはとれぞれの趨勢なりについて扔話しいただ きたいと思います．今度はひとつこっちからや。 ていきましょう。特別そういうお話がなければな いでけっこうです。

野中 睪丸腫陽の場合なんかはだいぶ大きな転 移を後腹膜にたくさんコングロメラートを形成す ることがありますけれども，血管侵襲のあるもの までは積極的にはとっておりません。

長峰 頚ガンの場合第 3 期ということになりま すが，骨盤壁のリンパ節まで転移がいった場合， も5血管にへばりついて和りますので，血管とと もに転移したリンパ節をとるというやり方があり ます。実際そのことをやって和る人もあります が，ただそのような症例はリンパ節だけでなしに 膀胱, 直腸のほうにも浸潤がいっているのが普通 でございますので，骨盤壁だけでは片手落ちで， 膀胱ないし直腸までとらなきゃならぬということ になると思いすす。

村上，血管のみならず隣接臟器への 合併切除と いうことが問題になる。

長峰 そういうことです。

村上 場合によっては，そろいらことも行なっ ている.

長峰 普通はあまりやって和りません．

河野 小児の汪うでは神経芽細胞腫なんか，特 飞後腹膜のリンパ節に転移して, さらに血管系に 浸潤して和りまして，われわれの経験では大血管 を切除した例はありませんけれども，できればと の汪うまでも進んでいく可能性が十分あると思い ます。

村上 現在はまだそこまでいかないが，将来そ 5いう可能性が大いにある.

河野 あると思います。

安井胃ガンの場合は, 通常はやって和りませ 几.

板谷 肺門型の肺ガンでは, 右の場合ですと上 大静脈症候群が出てまいります。とれから左です と，胸部大動脈に浸潤がいっていることがあるん
ですけれども，全国的な発表を見ますと，昭和33 年ごろから自家静脈あるいは人工のグラフトによ るパッチ，あるいはバイパスなどの手術が人工心 肺を使ってやって扣られるょうですけれども，私 ぞもでは全くやるつもりはございません，といい ますのは，それをやったからといってかなり手術 時間も長くなる.それからまた非常に術後の死亡 率が多いといらこと. しかも生存率ということで あまり芳しくないということでそういった症例は 放射線療法にまかせたいと思います。

千ヶ崎 脳外科の手術で脳内の血管を吻合した りする手術が最近発達しましたけれども，技術的 に可能だからといって神経機能が回復するわけで はありませんので，やはりそこまでやって手術を しても意味がないと思います。

三枝 整形の場合は全部切ってしまうんですか ら，血管移植ということはありません。

村上そういたしますと，いま血管に処置を加 えて根治性を増すという可能性を扮感じになって いる科は 1〜2 あったようですが，いまのところ はそこまでまだいっていない，そこまでは考えな いそそらいう場合には，むしろ他の補助療法を考

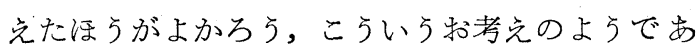
りますどうもありがとうございました。

それでは次の問題の，姑息手術に対する考克 方，とあげましたがこれは私のことばが悪うござ いましたので，姑息切除，というつもりであった わけです. したがって, その次の, 根治手術及び 姑息手術の予後の違い（たと壳ば 3 年〜 5 年生存 率), といった問題をひっくるめましてここで扰話 しいただきたいと思うんですが，一般的にいえ ば，姑息切除をやったときには，放射線療法であ るとか，化学療法剤であるとか，ホルモン療法で あるとか，そらいったものに依存するといら扔答 学が和允ら出てくるであろらと思います。しか し，そ弓いった補助療法分出てまいりましたの は，预そらく皆さまの科でもそう古い話ではな い. 数年前までは, やはり手術療法が唯一の治療 法であったという時代が長くあったと思います。 したがって，その昔の話がさしろ聞きたいんです 
が，姑息切除というものに対して，結局とれはな おらないんだ. ぞうせ 1 年か 2 年で再発するなら ば，根治ができないくらいならば，姑息切除はや らない㴗うがいいというふうに执考光になります か. それとも，多少でも延命効果というようなも のがあればやったほうがいいというふらに，姑息 切除というものに対して積極的な和考䒚を持持ち かあるいはおまり積極的ではないというふうに 抒考光になるか。ささらに，もしデーターを特持ち でしたらば，姑息切除と根治切除との違いが， 5 年生存率なり 3 年生存率なりにどのようにあらわ れているかということに扔蝕れいただければあり がたいと思います。

三枝 整形の場合は，先ほどちょっと申しまし たが，姑息的に，たとえば大腿骨頚部付近に腫瘍 がある場合に，骨盤のほうに転移があるか，ある いは肺の汪5にすでに転移があっても，非常に疼 痛がひどい場合には切除で人口骨頭を入れる手術 とか，そういうことをたびたび行ないます。成績 のほうは，切断しても非常に死亡する場合が多く て, ぞちらの場合も 3 年以上の生存率というのは 非常にむつかしいと思います．非常に成績は雳い と思います。乙かし，患者に対する疹痛の除去な ぞの目的で積極的にやります。

千ケ崎 脳腫㿟の中で悪性といわれるグリオー ムに関しては，先ほど申しましたように根治手術 というのは理論的にはあり觉ないので, 根治手術 と姑息手術を分けるというのはむずかしいのです が，ただいえることは，減圧手術か，単なる試験 切除に終るというような消極的な手術と，肉眼的 には根治手術に近い亜全剔を行ら積極的な手術, この 2 つを比べて多ますと，悪性のグリオームに 関して, 生存率に関しては必ずしもそれほど優劣 の差がないと思います。ところが大きな差異は， その手術をしたあとの患者さんの morbidityを考 えてみますと，亜全剔した場合には压倒的に患者 さんの症状が改善して，一時は少なくとも正常の 生活に戻り得る.ところが試験切除のみ行ったよ らな消極的な手術の場合はほとんど改善が見られ ないといら意味においてわれわれは今日ではたと
兄全摘が不可能であっても症状を悪化させないと いら条件のもとに，できるだけ広範囲にとるとい ら方針でいって拉ります。

板谷 結論から申し上げますと，私どもも千ケ 崎先生と同じょうに姑息手術を積極的にいたしま す.なぜかと申しますとわれわれの扱っている 症例が，ほとんどステージIII，IVの症例が大体 80 \%を占めて和りまして，肺ガンの場合は非常に局 所の症状が強いわけでございます。したがって， 胸膜，横隔膜，あるいは縦隔のほうに浸潤してお りました場合に，胸膜を切除したり，あるいは横 隔膜を切除したり，それから心膜の切除を致しま す. それは姑息手術となりますけれども，原発腫 瘍を含めてそういった隣接藏器といいましょう か，そらいったものを切除することによって少し ででも局所の症状をとってあげるということが非 常に大事じゃないかと思います。

それから，根治手術と姑息手術の成績ですが，

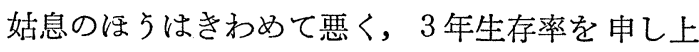
げますと，根治手術例では 3 年生存率が $33.3 \%$ で，姑息手術ではわずかの $4.8 \%$ でございます。

安井 胃ガンの場合も，やはり姑息手術はやる べきだと思います，根治手術と姑息手術の 5 年生 存率を見ますと，大体根治手術が50\%姑息手術の ほうは $4 \%$ 『゙す。

河野 小児の外科的悪性腫演の場合は, ウィル ムス腫の場合は $87 \%$ 全摘できておりますので問 題が少ないが神経芽細胞腫の場合は全摘除率が 悪 く問題となります.すなわち部分切除でもしたほ らがいいと云うことです. 特にこの腫湟の場合は スポンタンレグレッションを考えれば，とにかく 積極的にもやるし, 姑息手術の適応にもなると思 います。

長峰 子宮䅡ガンに対しましては始息的な摘除 は普通はやりません，と申乙ますのは，頚ガンが 子宮外に進展しているといらことでございますの で，炎の進展した部位を切除することになり，か えって悪化させるということからやりません。

それから，先ほど時間がなくて申し上げられま せんでしたが緁毛上皮腫で遠隔部位に転移がある 
そいらょうな場合，原発巣である子宮だけでも摘 除いたします。これはその原発巣を摘除して，そ の後に一いまは化学療法で有効なるのがあるの で大分違って来ていますが，そういうものがなか った時代でも肺の転移が縮小するというような症 例があったからでございます。

それから，これはいま括話ししていることと多 少ピントがはずれるかもしれませんが，ちょっと 申し上げてみたいと思います。先ほどもちょっと いいましたが，子宮の䅡ガンにつきまして，ごく 早期のものは，ぞちらかというと手術の範团を縮 小しつつあるといらのが現状でございまして，そ れはここでいま問題になっている姑息的な摘除と は意味が違うと思いますが，だんだんそういう傾 向になって和ります、これは，最近わりあい早い 時期のガンが数多く見つけられる様になり，とれ ら症例の全てにあとにかなりの障害を残す根治的 な手術をすべきかどうかと言うことから出ている ことでございます，範囲を縮めた手術によりまし ても，まだはっきりしたデータは出て和りません が，それ症ど予後に大きな違いはないだろうとい

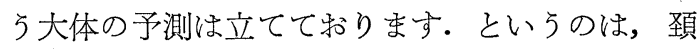
ガンといらことが子宮を摘除したあとでわかった 症例がいくつかおるわけで，そういらものを積み 重ねてみますと，簡単な子宮摘除だでもな拉っ ているといら事実があるわけです。

野中 膀脱腫瘍についてですけれぞも，膀胱と いうのは特殊な臓器でもありますから，できるた 将存という方式で，先活ども発表したと和り表 在性のものにはとにかくまづ姑息的な方法を行な います。をた，浸潤が少し進んだ場合でも，限局 性の場合には全摘を避けて部分摘除を行ないま 才.

村上どらもありがとうございました。

大体これで一応平均的には，姑息切除でも可能 ならば，あるいは必要があれば積極的にするとい ら和話が多らかったんですが，ただ子宮ガンの場 合だけ，あまり進久過ぎているものにヘルドの中 までメスを加充るということについては疑問があ ると，こういう和考光のようでございました。
また，姑息切除は，明らかに根治手術に 比べる と生存率が非常に悪い。これは皆さまの一致した 見解のようです。

では次の問題にまいりまして，放射線併用の価 值と制ガン剂の効用，ということでございなす が，ちょっと時間がなくなりましたので，これを 1つ1つやる時間は抒そらくないと思います。特 それ入りますが，補助療法ということで両方まと めていただいて，自分のところではこらいらケー スには放射線療法，こういらケースには制ガン剤 を使ってその価值を認めている，あるいはあまり 価值がないこういった和話をしていただきたいと 思います。したがって，そこの中へ先ほぞ叔話に 出たホルモン療法, 補助療法という意味でホルモ ン療法なども加兄ていただきたいと思います。ホ ルモン療法，それからいわゆる制ガン剂，放射線 療法, これは前照射までいきますと話がをた飛び ますので，一応後照射ということに，限って和話 をいただきたいと思います。こちらから……

野中 泌尿器科領域で放射線療法で一番感受性 があるのはセミノームです。これにはルチンの治 療として後照射をやって频ります。皇れからウィ ルムスも感受性がありますけれども，これはずっ と前の症例で術後照射を行ったと思いますが，ち ょっと記憶がはっきりしません。

それから化学療法の㴗うですけれども，全身的

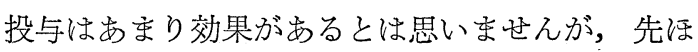
ぞ挆話ししたように膀胱腫瘍の場合表在性の腫瘍 には膀胱内注入療法というのは期待できると思い ます。

村上らょっと，失礼ですが膀胱腫㾤に対して は特別補助療法, たと光ば放射線……

野中浸潤性のもので手術を行なった場合に も，放射線を使って和ります。

村上これはコバルトですか，実際には.

野中 先注ど表に出しましたけれぞラドンシー ドを主にしています。

長峰 子宮頝ガンの術後ですが，放射線の深部 照射を行なって拉ります。ことにある程度進行し た症例に拈きましては，術後照射を加光る，加兄 


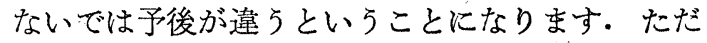
らんと初期の例ではむしろやらない活5がいいん ではないかという意見もあります。

それから，制ガン剤でございますが，頝ガソに 対してはこれを併用するといらことはあまり一般 的にはやられて和りません。あまり効果がないと いうことでございます．ですが，䄉毛上皮腫に対 しましては, 制ガン剤の効果は認められており必 ず併用するというのが現在の行きかたになってお ります。

村上その抗ガン剂は何ですか.

長峰 メソトレキセーテ (MTX) それからアク チノマイシンDでございます，それからさらに手 術ではなしに MTXなりアクチノマイシンDなり で, 化学療法だけでな技々うといらような考方方, これはもちろん䄉毛上皮腫までいったものには危 険かと思いますが，その前の段階といいましょう か破壊性胞状奇胎と申しまして, 子宮壁に胞状奇 胎が食い込んでいるような状態がございすすが， それに対しては手術ではなしにむしろそれだけで なおるとまななおったあとに妊娠したといらよ うな報告が数多く出てきております.

野中さっきちょっと落としましたけれども， 腎肉腫の例にコバルトとビンクリスチンを併用い たしまして，1例は18力月後に肺炎で死亡しまし たけれぞも， も5 人は 3 年以上生存しておりま क.

それからホルモンを落としましたけれども，前 立腺ガンにはホルモン療法をやって扔ります，か なり進行を防ぎますし，予後もよくなっておりま के.

村上 河野先生は, 先ほどおもにアクチノマイ シンDとかビンクリスチレとかおっしゃったんで すが，そのほかに何か和つけ加壳になることがあ れば.

河野 報告した通りですが，最近課題としては エンドキサンとビンクリシティンとを各週ごとに やるといらジェームスの併用療法等が効果的で す.

村上 効果は認められるんですか.
河野 効果は認められます。

村上それは先ほど同ったけれど，それじゃ大 体何例のうち何例ぐらいにきいて，何例ぐらいは きかないんですか.

河野 活とんどの例がある程度はきいておりま して, 子供の場合にはある程度の効果が期待出来 ると思いすす。

村上 子供のガンに対しては, 非常に化学療法 剂が有効であるということですね.

河野手術, 化学療法, 放射線療法三者による combined therapyですから，ぞれがぞのくらいと いうことはちょっといえませんが…...,

村上 栗原先生, ここで何かひとつ内科の立場 から……皆さんの预話を聞いていて撼じにな ったことでもけっこうです.

栗原 内科の立場は補助療法じゃなくて, 化学 療法が主療法なわけで，そういら意味では一い ま私は内科 (消化器) という場に置かれておりま すので, たまに消化器原発以外ですと乳ガンの肝 転移なんかを扱らことになります。肺転移は内科 (呼吸器) の活うに回ります。かつてガンセンタ 一に拉りまして，㴗とんどの科の最後のめえぞう を見さしていただくのは内科というような，そう いう立場からしますと, 肺転移の場合に diffuse にみられる転移巣が 2 センチ以下のものだったら 大体化学療法で消せる・肺の影は消せたんだけれ ども残っている原発疾患のために患者さんは倒れ てしまうといらことを経験しました。ですから皆 さんが，姑息手術に対しても積極的に取り組んで くださるということは非常にありがたい，そうい ららうに思います。

それから，先ほど私が出しました 2 つの症例の ように今迄は胃ガンの場合にはレントゲン所見ま で改善するということは非常にむずかしかった。 とい觉ると思います。ですから，非常に高齢者の ガンの場合，それから手術を拒否した場合には， 試みるべき治療法だし，さらに一たん手術できな いと見離されたガンを，制ガン剂治潦をさせてい ただくことによって再び手術を受けられる状態に して，その一命を救い得ることが，将来にもかか 
わることですが，期待できるんじゃないかと思い ます。

放射線に関しては，噴門のガンに対しては放射 線を併用しているところが他大学の外科であるの でございますけれども，内科的にも5-FU とコバ ルトを使うというような方法は, 積極的に試るこ とによって通過障害をなくして延命を期待できる んじゃないかと考えております。

それから，きょうは和話に出ていませんけれど も，食道ガンに関してはブレオマイシンと放射線 の併用というのがいいようで，私たちにもかなり いい症例があります。

安井 マーゲンの場合は, ある大学ではベータ トロンを照射しているところもございますが，う ちの場合はマーグンにはやっておりません.

村上 コバルトをやってないんですね.

安井 党，コバルトもやっていません。

制ガン剂の泀うなんですが 5-UF とか MMC と かエンドキサンとか，そらいうものをある程度基 準をきめて使用はして和りますが，まだはっきり した結果は出ておりません、これがきいたかきか ないかというのも，どういうのがメルクマールに きいたかきかないかという議論になってくるわけ ですけれども，まだとこまでいっておらないよう です。しかし有効と思われる例はありました。

板谷 肺ガンの場合は術後照射でございますけ れぞも，コバルトを使用して和ります。どういっ た症例に使うかと申乙ますと，手術の際に縱隔り ンパ節の取り残しがあったと思われるもの， それ からたびたびかなり中枢の気管支に転移したリン パ節が浸潤していることがございます，それはど らしても取り切れませんのでそらいった症例. そ れから胸膜に浸潤したようなものは，たと光切除 しても，そこにリングを突っ込んで，あとから必 ずコバルトを照射するようにします。

それから化学療法ですけれども，肺ガンの場合 は血行転移が多いわけでございまして，少しでも 潜在性の転移病巣の增殖を抑制しょうということ で, 現在”5-FU, マイトマイシン，それからェン ドキサン, ブレオマイシン，そらいったものを全
身的に，経静脈的に，術後長期にわたって使用し ております。それからこれはつい最近始めたんい ですけれども，術前に気管支動脈内にマイトマイ シンを注入しております。これは，気管支動脈は 肺の病巣に非常に密集しておりますところから, なるべく原発巣に高濃度に制ガン剤を注入して， 少しでも腫瘍が小さくなり，それで手術が可能に なれば非常に手術適応の拡大とい5ことにもなる と思って，これは目下検討中でございます.

それから，コバルトあるいは制ガン剂でござい ますけれぞも，これは特に肺ガンの場合だけかも しれませんけれども，やたらに使用するのではな くて, やはりこれからは細胞のタイプに従ってコ バルトないし制ガン剤の選択というものを厳密に 行っていかなければいけないと思います。

村上それはわかりますが，じゃそのタイプに ついて, こういうタイプはこの薬がいい,これは きかないという見分けのしかたについてめどが立 っていますか.

板谷 数例はっきりレントゲン上の影が 小さく なった症例がございます．私ども一応未分化癌に 対してはコバルト，偏平上皮ガンに対してはブレ オマイシン,又はコバルト.腺癌は㴗とんどだめな んですけれども,一応腺ガンに対しましては 5-FU とマイトマイシン，それからエンドキサンをミッ クスに使用して和ります。

村上そ5い5ものを和使いになっていて，多 少でも効果があるとあなた自身拈感じになって拈 りますか。みんながやるからやってみて，そのう ちにきくのがあればといら程度でしょらか。どの， 程度の期待を持っておられるか。

板谷 正直申し上げまして，やらないよりはや ったほうがいいだろうと，そんなばく然とした気 持ちでございます.

一応 3 年生存率を申し上げすすと，ただこれは 症例が非常にばらついて和りますので問題がある んですけれども，切除のみですと 3 年生存率が $12.5 \%$ でざいます. 切除十化学療法, これは $23.1 \%$ ，切除十照射は20\%でございます.

村上 ちょっと安井君に戻ってください。あな 
たもいまの化学療法をやってはいるという和話で したが，やりっぱなしではなくて，それに対する 印象をひとつ.

安井 ちょっと調べてみたんですが，これはま た 3 年しかたって和りませんので……切除しな いで，乙かも化学療法もしないのが，3年生存が $9 \%$. 切除しないで化学療法を使ったものが $26 \%$ の 3 年生存率. それから一応治療切除をやりまし て，化学療法をしない 3 年生存が $57 \%$. 治癒切除 して，その上な预かつ化学療法をしたものの 5 年 生存率が70\%ということで，3 年生存の範囲では 使ったほ活うがいという化学療法班の報告がきて おります、私は，まだ全部調べたわけでありませ んのでわかりません。

村上おなた自身の印象は？

安井はっきりしたものを持っていません。

千ケ崎 初めに化学療法のことを申し上げます そ, 悪性脳腫瘍の中で私たちが経験しまして, 確 実に化学療法，たと壳ばビンクリシティンだとか 5-FU などがきいたという例は，ほとんどが原発 性の肉腫のような病理学的中胚葉起原性の腫瘍が 大部分でして，本来の脳腫瘍である神経上皮性の 腫瘍に対しては，正直のところ確実に化学療法剤 が著るしく効果があったという症例はあまり経験 していないわけです. 現在のところは，やはり化 学療法よりも脳腫瘍の場合には放射線療法のほう が有効であるということは確実でして，ただ普通 の放射線療法をやるよりは，われわれがいま試み ましたような BAR 療法のように，放射線の感受 性を高めてやるいらんな手段を講じてみるとか， あるいはきょうは申し上げませんでしたけれど も，放射線療法の 1 つ属寸る硼素中性子捕捉療 法とか，そらいうような特別なテクニックを使っ て行な党ば，今後さらに有望ではないかと考党て 特ります。

三枝 整形領域では，まず放射線療法ですが， osteoid をつくるような ostcosarcoma あるいは 軟骨肉腫のようなもの，こういうものには一般に きかないといわれて和りますが，一たん手術をし て再発したような場合には，やはりほかに方法が
ないので制ガン剤も投与しますが放射線療法を主 に行ないます。とれから multiple myeloma とか reticulo sarcoma，あるいは fibro sarcoma のよ らなものには非常に効果的だと思います。で，術 後必ず照射をするようにして和ります。も51つ giant cell tumor というのがありますが，1度か ら 3 度までに大体分かれて拉りまが，2 度ない し 3 度は非常に悪性の傾向があるので切除術， お るいは切断ということも考光るのであります。こ れに対しては放射線療法が一般的に非常に効果が あるから行ならべきだという人と，むしろ行なう べきでない，かえって post irradiation sarcoma といって悪性化するという意見もあります，私自 身の印象としては, giant cell tumorに対しては, 放射線療法を行なわない活らがいいと思って和り ます。

それから楽物療法でございますが，これは先生 方拐っしやい屯したように，5ちでも一応ナイト ロミンとか, マイトマイシンC とか 5-FU の全身 投与も行ないますし，局所灌流も 2 〜 の例しか まだ経験がありませんが行って扣ります。矢れか ら最近 2 〜 症に，胸部外科にこれはご持導を いただいてやって和るわけですが，気管支動脈へ のインフィジョンを試みをした。今後いろいろ教 えていただかなきゃならぬと思っております。

それからホルモン療法は，転移性のガン，つま り前立腺ガンとか乳ガン，子宮ガンのようなもの に対しては，骨に移転した場合にこれは非常に効 果的だ思いるす。そして，このような腫瘍には ホルモン剂投与で一番整形の悪性腫瘍の5ちで延 命効果がはかれるもので，ホルモン療法は非常に ぼくはきくように思います。

村上 結局整形外科では，いろんな異なった種 々のものを取り扱って执いでになるので，そのも のに合うようないまの補助療法を使う必要がある ということになりますね.

\section{三枝 はい。}

村上扮气れ入りますがも51回戻していただ きたいんですが，拉宅の科で楽局へ一番多く注文 の出る制ガン剤は何ですか。たとえばマイトマイ 
シンであるか，5-FU であるか。

三枝 エンドキサンとマイトマイシン，とれか ら 5-FUこの 3 つだと思いますが，エンドキサン が一番多いかと思います。

千ケ崎 最近ではビンクリシティン，あるいは 5-FU, メトトレキセイト，ブレオマイシセンが使 われています。

板谷 MMC 5-FU エンドキサンが一番使われ て和ります。

安井 5-FU, MMC，エンドキサン.

栗原 先济ぞ申しました $\mathrm{FAM}_{2}$ が，いま安井先 生いわれた 3 種になります。他に cytosine arabinoside，これがかなり希望が持てるんで........ だサンプルの状態なんですけれども.

河野 エンドキサン，ビンクリスティン，アク チノマイシンD.

長峰 5-FU，マイトマイシン，エンドキサンで しょうか。それから先ほど申しました絨毛性腫瘍 に対するメソトレキセート。

野中 マイトマイシンが多いと思いむす。

村上ぞうもありがとうございいました。

ここで，いろいろ各科によりまして放射線療法 に対する考え方なり，制癌制に対する考方方が違 っているということがわかりましたが，長瀬先生 があとこにおいでになるんですが，筒単にひとつ， そんなことをいったってみんな和れのところへ泣 きついてくるじゃないかという和考克がありまし たらそれでもよろしゅうございますし，逆に先生 のほうにもまた，この科から来たやつは困る，だ けどここの科から移ってきたやつは和れはすきだ と，并らいうすききらいがあると思うんです。 そ んなところでもよろしゅうございますから，一言 ちょっとつけ加完ていただきたい。

長瀬 いまの事ですが，すききらいをい兄とい われると放射線科の泀万でうまく治療してくれい とわれるのが一番やりいいわけでございまして， 機械もあまり見たこともないような先生からこち らの活らから照射したらいいだろう，なんていわ れますと，機械の都合上全然照射できないといら ような場合もあるわけでございまして，おまり注
文はつけられない汪うが一番やりいいというょう な感じがいたします。

も51つやりにくいのは，化学療法を行ないま して，そのあとでだいぶ小さくなったから治療し てほしいというのが時々ありまして，この様な症 例は非常に治療し憎いわけでござい屯して，この ごろのブレオマイシンと放射線の併用の研究会が ございますけれぞ，ブレオマイシンで治療したあ と放射線治療をするとか学って広がるんじゃない かと・どうせ併用療法をするんだったら，一緒に 使った洼らがいいと，まだ結論まではいって和り ませんが，そんなような傾向がございすす。

村上 ぞこの科の腫瘍がかけやすくって，患者 が一番喜ぶからすきだとか，きらいだとかはあり ませんか。

長瀬 それはやはり肺なら肺の部位がございま して肺の上部で中心部にあれば一番治療しやすい わけですが先汪ども話が出ましたと和り未分化ガ ンでございますと鷄卵大より少し位大きくても根 治的にな和す自信はございますけれぞも，その汪 か腺ガン，扁平上皮ガンですと，もう鷄卵大以上 というのはちょっと根治的照射はしたくないとい らようなことでございます。今述べました様に照 射しやすい部位ならばよいのですが照射し憎い所 に大きな腫瘍のある時などはなるべく始息的な手 術でもして大きいところはとっていただいて，と のあとで照射したいというふうに考壳ておりま すे.

村上 その浪何かここに並んでいらっしゃ る先生に注文はありませんか。

長瀬 別に……

村上 特別に和話しいただいて，どうもありが とうございました。あと 6 時京でも5 5 分ほどあ りますから，もう少しつきあってください。

では次は，術後の機能欠除に対する対策.これ は, 根治手術というものが進めば進む注ぞ, 術後 の機能欠除は大きくなるとい5矛盾がございま す.これは外科手術としての1つのジレンマでは ありますが，これは一番初めに三枝先生がそのこ とは特に強調しておっしゃいました。これを特別 
に考えているか：あるいはそらだけれどもも5し かたがないとしてあきらめている，要するに根治 手術をすれば，あとのデフェクトが大きいのはや むを得ないじゃないか。命と引きかえだから文句 をいうなといっちゃこの時代いけませんが，乙か たがないというらうに和考觉になっているか，そ れを積極的にこうやって救っていくという考觉を 排持ちになっていらっしゃるかということを和っ しゃっていただきたいんです。

三枝これもやはり積極的に行なっていきま す.と申しますのは統計的に生存率を考光ます と, 整形の腫㴡は非常に将来, 予後が暗いのであ りますけれぞも，切断したあと必ず義肢をつける ようにしまして，場合によっては長岡の分院のほ らでハビリテーションをさせて，ときどきまた B.T 診 (骨腫瘍特別診) でフォーローアップする といらことにしております。

しかし，術後に，先ほども申し上げましたよう にメタスターゼがないと思って退院させまして も，義足をつけて 3 カ月後ぐらいになりますと肺 に転移陰影が出てくる. それで，大体 1 年か 1 年 半ぐらいには再び入院するよ5になって死亡する ということが非常に多くなっております。

そして，現在フォローアップしている患者が 2 人ございますが，それ以外は皆義足を一たんはつ けて日常生活できるようになりましても，1年間 ぐらいで死亡しているというのが現状でございま 于.

千ケ崎 先ほど申しましたように脳腫瘍の手術 の場合, 無理な手術をして完全な神経機能の脱落 を示した場合には，術後のリハビリテーションを かなり強力にやってもかなりの障害が残るという ことがありますので，手術に対してかなり術前に 慎重を期しております。

板谷 私たちが扱っている肺ガンは，患者さん の年令層が50代から60代で，乙かも肺ガンとい5 疾患が肺気腫を合併することが多いので，乙たが いまして，無理に全摘を行ないますと，手術は比 較的よくいっても術後もとの仕事に戻れない，注 えとにうちの中にいるっきりといった生活になる
ことも考觉られわけです、ですから，先ほどい いましたように，なるべく全摘は行なわない。で きるだけ葉切だけにとどめるといらことにしてお ります．とれから，術後数回は必ず外来て肺機能 を調べるようにして和ります。

安井 胃ガンの場合は，その胃ガンのできてい る場所によって胃袋を残す程度が変わっていいり ますが，できれば命との引きかえでございますの で，全摘もやむを得ないと思って和ります。

河野 小児の注うでは, 両側性のウィルムス腫 瘍等が大きな問題です。．ただ腫瘍をとればいいと いうことではないからです。両側腎部分切除, 片 側全摘，他側腎部分切除等のいろいろな手術方法 が考学られますが，現在の段階では腫演の部分を 積極的にとると云う事が中心です。これは腎移植 と云うところまで問題が 発展するんじゃないかと 思います。その他アクチノマイシンDとかいろい ろな制ガン剤を非常に長期にわたって使っており ますが，この副作用しての発育等への影響も考慮 しなければならないと思います。

長峰 子宮の機能と言えば妊娠分べんといらこ とになりますが悪性腫瘍ではあきらめざるを得な いと思います。術後の機能障害の対策ということ になりますと，子宮そのものよりも問題を起こし， ますのは子宮, 基勒帯を含めかなり広くとること から起る尿路系(膀胱・尿管)への障害でございま すので，それをできるだけ少なくし，乙かも根治 性をとこなわないというようなやり方が最近とら れて和ります。その1つといたしましては，骨盤 神経を全部保存することはもちろんできないわけ ですが，でさるだけ残すというふうなやり方，こ らいらくふらがされて和ります。

野中 泌尿器科ですと, 膀胱以外の臟器なら根 治的な全摘, 乙かし膀胱の場合ですと先ほどのよ らな尿路変更といらことがありますから，それに より予後も相当影響されます。ですから，可能な 範囲ではなるたけ部分摘除をしたいと思って抹 ります。

村上どらもありがとうございました。 たいへん過酷の質問をして，演者の方にはずい， 
ぶん不快の念を持たせたかもしれませんが、これ こ はごかんべんください。

さて最後の, 将来に対するVision, といらこと につきまして，いやな答觉を強いましたので， 今度はここでひとつ大いに执れは今後こ5いう夢 を持っておるんだと：先ほどもどなたかおっしゃ いましたが，凍結療法とか，あるいは超音波の集 束破壊であるとか，こ5いったような私どものあ まり知らない一知らないといらことは学校で教 えてもらわなかったといらことですが一そつい う新しい治療法が続々と打考えられているようで す. そ5い5ものに対する希望も含めてひとつビ ジョンといいますか希望を1つ1つ，まあ早くい えばほらを吹いていただきたいと思います。

野中いま凍結療法の話が出ましたけれども， 前立腺ガンのような場合ですと，進行したものは 全摘を行ならよりもホルモン療法を行い，必然的 に下部尿通過障害を起こしますから，それに対し ては凍結療法で下部尿通過障害をとってやるとい らのが，いまのところ一番いいような感じがいた 乙ます。

それから膀胱腫痬の進行した症例は一番てこず るわけですけれども，将来やはり放射線とか，お るいは化学療法のほうにもう少し研究したいと思 って和ります。

長峰 手術療法と申しますのは, 病巣を完全に 取り去ってしまう非常にクリアカットな療法であ るこれは間違いないことだと思いすすが，どう しても先ほど来問題になりますようにいろんな機 能障害を残すことがあります。そういうことで，

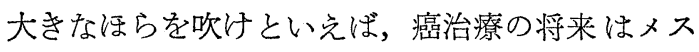
を捨てることにあると言いたいと思います，その 一つの踏み台を，われわれは䄉毛性腫瘍の治療に 和ける化学療法の効果に見出しているよ5な気が いたします。これはまだまだ完全にそれだけでな おるというところまではいって和りませんが，全 てのガンにきくような化学療法剂が将来出てメス をとらなくともすむようになることを希望してい るわけでございます。

それまでの問題，これは現在でもやってやれな
いことはないことになりますと，子宮頝ガンによ る死亡をゼロにすることです，子宮䅡ガンという のは非常に検查がたやすいわけでございます，胃 や肺など深い臟器の検査はたいへんだろらと思い ますが，子宮頝ガンに関する限りはすぐ届くとこ ろにおるわけでございますから，検査の対象を広 げていくことにより子宮䅡ガンのすべてを早い時 期に見つけ出すとことができるわけでございま す.これによって死亡をゼロに近いところまで持 っていくことはでさるだろうと思っております。

河野 小児期の外科的疾患のなかで悪性腫瘍と いらのは全体から見ればわずかですけれども，そ のわずかなものでも全例助けていきたいと云う事 です. 現在の段階ではやっと注目されるよらにな ったと云ら所でこれからの問題だろらと思いま す.

栗原 内科で現在ガンを报うといらことは，非 常にみじめです。ですから，将来に対するビジョ ンといらのは, 内科のガン医者というのは非常に 夢を大きく持つわけですけれど……私が特に関 係があるのは現状では, 最も内科的治療の難しい 胃ガンですけれど，㴗らを吹けといわれれば，ガ ンは「内科でな执してやる」といいたい、そうい うような時代がくると思う．というのは，ガンと いうのは全身性の疾患だと思らんです。早期診断 は，これは非常に大切なことですし，事実かなり の好成績をあげているのですが，大部分のガンが 手遅れという現状を考学れば，ガンが転移を有す る以上これは内科的な疾患になる。先ほど長峰先 生がメスを捨ててくださると抽しゃったけれ ぞそそらいらことに大いに希望を持ちます。

ただ現状では，あまりにも現実的な話に戻るん， ですけれども，外科の先生が抒やりになって，化 学療法に期待を持たないといいながら、けっこう 化学療法を現実に使っていてくださる.ですから 効果を上げるには，そ5い5化学療法剤による一 過性の治療で放置されないで, 即ち, ガンをある 一定の期間の治療だけではたたくことは拈そらく 不可能だと和考觉いただいて（そらいうことがい まの生存率に関係があると思いますので), 繰り返 
乙繰り返し継続的に治療をしてほしい。とれから 内科に回していただくとさには，再発を早期に診 断して，早期に内科のほうに回していたたききた い. 担ガン生体では, 先ほどもちょっと申し上げ ましたけれども，一般に凝固能が低下して線溶能 がえ進しているということは湮济認められてい る・従って，いま中検で簡単にはかっていただけ ないのが残念なんですけれど，Fibrinogenを測定 していただきたい。これは科量法ですと比較的簡 単なのです. Fibrinogen がかなりの高值を示すと きには，体内のどこかには遠隔転移があるという ふうに考㝋ていただいてよろしいと思います，そ の時点で，なるべく早期に治療してほしい，そう 思います。

安井 いま栗原先生が話したことに尽さると思 いますが，1つのキャンサーセンターのようなも のをつくって，そこで消化器だけでなくすべての ガンの治療なり研究に当たるといらような方向に もっていってもらいたいと思います。

板谷私ぞもは，現在の段階に和きむしては， ガンは外科療法が最も有効であると思って和りま す.しかし，肺ガンの場合は非常に切除率が悪い のでございますけれども，そういった意味で何と かして切除率を向上させるためには，どうしても 早期に発見しなきゃいけない，胃ガンの場合は特 飞内視鏡が発達していますが，残念ながら肺の場 合には胃と違いまして解剖学的に構造が複雑でご ざいます.したがいましてフレキシブルファイバ ースコープがありますけれど，それも非常に䛦断 率も限られてまいります。したがいまして，でき ればもっと容易で確率のいい診断方法，できれば 超音波などを利用して，もう少し診断率が上がれ 蝶いいと思っているわけでございます。

それから，われわれに送られてくる患者は，泀 とんど実地医家の㫮様方から送られてくるわけで すけれぞも，大体レントゲン上陰影が出てから 6 カ月，悪い場合ですと 1 年経過してからこちらに 参ります。したがいまして，患者さんに対する肺 ガンの認識と同時に，実地医家に対する肺ガンの 認識を高めるように努力し，そしてわれわれ大学
病院も積極的に, 集団検診というものをもら少し 重要視しなければならないと思っております。

千ケ崎 今日脳腫瘍の手術的な問題に関しては ほとんぞ技術的に完成されて和りますので，治療 成績をあげるためにはどうしても補助療法を今後 大いに発展させなければいけませんが，化学療法 に関しては，先ほどものべましたように，脳腫瘍 はむる意味に和いては薬物をその腫瘍組織にかな り高濃度に集中することがでさるという特殊性が ありますので，いい楽剤さ壳できれば非常にいい 適用ではないかと考壳ています。兵らいらわけで 確かにきく薬剤待ちという状態です。

それから，放射線療法関しては，私も先㴗ぞ 述べましたようにまだまだ有望ないろいろな方法 が残っていると思います，1つは，何らかの方法 で, 腫癔組織のみの放射線感受性をあげて, 正常 組織は障害せずにもっと大量にかけられないか。 あるいは，いままで行なってきたガンマー線を利 用する方法ばかりでなくて, 重粒子線, たと觉ば 矹素中性子捕捉療法に和村るアルファ線とか，あ るいはプロトンビームによる方法とか，そういう 新しいものを使兄ば，もっと能率的に腫瘍組織だ けを破壊できるんではないか，そういうような考 光もしますので，まだまだ発展性があるのではな いかと思っております。

三枝 整形の領域の予後が悪いことは, 过5 先 ほぞから再三申し上げて和るのでありますが，ま ずわれわれの外来のところに来た場合に，非常に 進行しているケースが多い，それで，まず診断で は，早期猃断といらことが胃ガンなんかの場合の ようにできればいいなというらうに私は考㝋て拉 ります。整形の場合に小学生の足を集団検晾で毎 月のよらにレントゲン写真をとるといらわけにも いきませんので問題があると思いますが，例へば osteosarcoma を考光て夕女すと，開業医の先生の ところで 3 カ月前ぐらいから見て和ったというこ とで，レントゲン写真に変化があった．神経痛の ような症状で痛久がある, あるいは関節痛のよう なことで， 3 カ月ぐらい経過して参りますと，先 ほぞスライドでお見せしたような進行状態になっ 
ていることが多い，それで，ほかの科の先生で も，いろいろな病院に出て抢られてそ5い5もの を発見されたら，登録する意味もございますので, 整形のほうに持ってきていただきたいと思いま 于.

それから治療についての夢ですが，先ほぞ超音 波ということを申し上げましたが，確かに osteoid をつくるような硬いものには放射線があまり感受 性がないということは一般にいわれておるところ であります。それで，超音波では，理論的には， かたい腫演なほど破壊効果があるということをい われて拉ります。私は堀江肉腫を使いまして，皮 下腫癔と骨髄の移植腫湯の両方を使って実験をや った結果では，骨腫瘍でも軟部腫瘍でも同じょう な効果を示しました。したがって，そういった腫 瘍の破壊というものを超音波でもかなりできるん
ではないかと思います，そして現在，照射量や血 管に対する効果などをチェックした上で臨床応用 を開始しました。私は終局は，やはり先生方皆さ ん和っしやいましたように，化学療法，内科的な 療法で，メスを加えずになおるといらことが理想 だとは考党ております。

村上どうもありがとうございました。

私の注文が少し多過ぎたかもしれませんので, 時間をだいぶ超過いたしました。ほ沈とうはフロ アの核らからもご質問があればお受けする汪らが いいとは思って和ったんですが，どうも時間の超 過が激しくなりましたので，一応予定の討論を終 わりましたところでこの会を閉じたいと思いま के.

どうも皆様，長時間ご清聴いただきましてあり がとうございました.（拍手） 